\title{
КРИТЕРІЇ І РІВНЕВІ ХАРАКТЕРИСТИКИ ПІЗНАВАЛЬНОЇ АКТИВНОСТІ СТУДЕНТІВ ВИЩИХ ПЕДАГОГІЧНИХ ЗАКЛАДІВ
}

\begin{abstract}
Чувасова Н. О. Критерії і рівневі характеристики пізнавальної активності студентів вищих педагогічних закладів.

У статті розкрито критерії $i$ рівневі характеристики пізнавальної активності студентів вищих педагогічних закладів, розглянуто шляхи та методи розв'язання проблеми визначення рівня сформованості пізнавальної активності студентів.

Ключові слова: пізнавальна активність, критерії,структурні компоненти пізнавальної активності, рівні сформованості пізнавальної активності студентів.

Чувасова Н. А. Критерии и уровневые характеристики познавательной активности студентов высших педагогических учреждений.

В статье раскрыты критерии и уровневые характеристики познавательной активности студентов высших педагогических заведений и рассматриваются пути и методы решения проблемы определения уровня сформированности структурных компонентов познавательной активности.

Ключевые слова: познавательная активность, критерии, структурные компоненты познавательной активности, уровни сформированности познавательной активности студентов.

Chuvasova N. Criteria and leveling characteristics of the cognitive activity of students in higher educational institutions.

In the article the exposed criteria and level descriptions of cognitive activity of students of higher pedagogical establishments and ways and methods of decision of problem of determination of level of formed of cognitive activity of students are examined.

Key words: cognitive activity, criteria, structural components of cognitive activity, levels of formed of cognitive activity of students.
\end{abstract}

Постановка проблеми. Питання активізації пізнавальної діяльності студентів відноситься до найбільш актуальних проблем сучасної педагогічної науки і практики. Реалізація принципу активності в навчанні набуває великого значення, оскільки навчання і розвиток мають діяльнісний характер, і від якості вчення як діяльності залежить результат навчання, розвитку і виховання особистості.

Аналіз останніх досліджень і публікацій. У класичній гуманістичній педагогіці проблемі формування пізнавальної активності в усі часи було приділено значну увагу. Так, важливу роль пізнавальної активності у формуванні особистості підкреслювали Я. Коменський, А. Дістервег, Й. Песталоцці, К. Ушинський та інші науковці. Питання обгрунтування сутності пізнавальної активності у процесі навчання знайшли відображення в дослідженнях дидактів, психологів, методистів: Л. Арістової, Д. Вількєєва, Е. Голанта, М. Данилова, Т. Кудрявцева, I. Лернера, М. Махмутова, В. Онищука, Н. Половнікової, В. Пилипчука, О. Савченко, М. Скаткіна, Л. Скуратівського, Т. Шамової та інших.

Мета статті: визначити критерії та рівневі характеристики пізнавальної активності студентів, розкрити шляхи та методи розв'язання проблеми 
визначення рівня сформованості пізнавальної активності майбутніх учителів, зокрема вчителів хімії та біологіі.

Виклад основного матеріалу дослідження. Ми виходили 3 того, що пізнавальна активність - це складне особистісне утворення, яке є важливою характеристикою особистості студента. Процес їі становлення - складний і динамічний, який припускає безперервність, систематичність, цілеспрямованість. Ми визначаємо пізнавальну активність студентів як складне особистісне утворення, що складається 3 мотиваційного, операційного та особистісного компонентів.

3-поміж критеріїв пізнавальної активності виокремлено потребу в пізнавальній активності, мотивацію, прагнення до удосконалення пізнавальної активності, розумові операції й уміння, самовдосконалення та самовпевненість особистості, самостійність при виконанні навчальних завдань, наявність пізнавальних інтересів, характер діяльнісних стосунків 3 викладачами і одногрупниками. Теоретичні дослідження показують [3], що для кількісної оцінки складних педагогічних характеристик студентів доцільно використовувати так звані структурно-системні критерії пізнавальної активності, що відіграють роль моделей-еталонів. Структурносистемний критерій пізнавальної активності як інструмент, за допомогою якого здійснюється вибір ознак, які нас цікавлять, i їхній вимір, має суб'єктивний початок, закладений у момент його конструювання, і об'єктивну міру, що дозволяє подати педагогічну величину в кількісних показниках із визначеним рівнем точності. Алгоритм побудови критерію такий:

- чітко сформулювали, з якої метою нам необхідний критерій і в чому полягає педагогічна задача виміру;

- розглядали безпосередньо об'єкт дослідження, аналізували всі основні його ознаки, що задовольняють задачі дослідження; відбирали 3поміж них тільки істотні, котрі можна взяти як елементи еталона;

- сформували структуру критерію: у вершину логічного дерева поставили ознаку, яка нас цікавила, інші розмістили в нижньому ярусі грифової моделі як супідрядні;

- визначили вагові коефіцієнти в еталонних ознаках статистичним методом; нормували отримані значення; опускали ті ознаки еталона, у яких ступінь значимості склав величину менш 0,5 (це значить, що вони не здійснюють істотного впливу на кінцевий результат дослідження);

- розробили вимірювальну підструктуру критерію: для кожної еталонної ознаки підібрали серію супідрядних йому ознак (не менш шести), що характеризують його розвиток або зміну в реальних ситуаціях експерименту, що необхідно для виміру й оцінки його рівня сформованості;

- розробили норми оцінювання для елементів вимірювальної підструктури критерію у вигляді бальної або процентної системи оцінювання; можна взяти альтернативну систему («так» - ні»), що дає більш вірогідний результат стосовно градаційних шкал виміру, зате проста в звертанні і легко використовується в дослідах як вимірювальний інструмент. 
У підсумку одержали чітко окреслену значеннєву структуру критерію, що складається 3 трьох основних частин: узагальненої характеристики досліджуваного об'єкта, який є метою педагогічного виміру; еталонної системи ознак, що синтезує в собі найбільш істотні (відповідні цілі дослідження) його сторони, і вимірювальної підструктури, що складається 3 пучків із градаційними елементами, супідрядних відповідним ознакам еталона. У логічно зумовленому стані такий критерій набуває форми деревоподібного графа. Наведене вище переконує, що до його структури застосовано всі основні закони, якими описується системний об'єкт, і що його головною перемінною $є$ інформаційна характеристика.

Вимір - найважливіша функція структурно-системного критерію. Сутність їі полягає в тому, що еталонна структура критерію відображає в собі (з тією або іншою точністю) стан досліджуваного педагогічного об'єкта за ознаками, що нас цікавлять (спеціально нами віднесених до еталону), і рівень ïx сформованості (зумовленого за допомогою вимірювальної підструктури).

Оскільки педагогічний об'єкт, а відтак, і його модель - «не прості феномени, то і критерій, за допомогою якого ми будували вимір, $є$ складним структурним утворенням. У даному випадку ми взяли логічно розгалужений значеннєвий критерій, у якому у взаємозв'язку відбивалися характеристики, що нас цікавили. Звідси висновок: критерій - це система найбільш істотних ознак, що відбиває не весь розглянутий об'єкт, а тільки ті його сторони, що відповідають меті дослідження i які підлягають якісно-кількісній інтерпретації, тобто вимірові.

Шкала, якою виміряється ступінь відповідності досліджуваного об'єкта параметрам структурно-системного критерію, має логарифмічний характер і виражається інформаційною величиною:

$$
\mathrm{H}=1,443 \mathrm{p}_{\mathrm{c}} \ln \left(\mathrm{e}^{3} \mathrm{p}_{\mathrm{c}}{ }^{3}+\mathrm{e}^{2} \mathrm{p}_{\mathrm{c}}{ }^{2}+1\right),(1)
$$

де е - кількість ознак (вимірюваних елементів) у розглянутому пучку зв'язків критерію; $\mathrm{p}_{\mathrm{c}}-$ середній ступінь сформованості вимірюваної ознаки; $0,0<\mathrm{p}_{\mathrm{c}}<1,0$. Очевидно, визначення значення «Н» за єдиною інформаційною шкалою зводиться до перебування значення «р», що інтегрується на сукупності вагових коефіцієнтів і коефіцієнтів сформованості еталонних ознак об'єкта дослідження. Як еталонні ознаки в критерії є такі п’ять елементів:

$\mathrm{B}_{1}-$ потреба в пізнавальній активності на грунті переконаності в іiі значимості для особистості та в суспільстві; $\beta_{1}\left(\mathrm{~B}_{1}\right)=1,0$;

$\mathrm{B}_{2}$ - мотивація, прагнення до вдосконалення пізнавальної активності, обставин і самого себе; $\beta_{2}\left(\mathrm{~B}_{2}\right)=0,8$;

$\mathrm{B}_{3}$ - самостійність, наявність пізнавальних інтересів, характер стосунків з викладачем і одногрупниками; $\beta_{3}\left(\mathrm{~B}_{3}\right)=0,8$;

$\mathrm{B}_{4}$ - розумові операції й уміння, властивості мислення ; $\beta_{4}\left(\mathrm{~B}_{4}\right)=0,8$;

$\mathrm{B}_{5}$ - самовдосконалення та самовпевненість особистості, яка включає творчий компонент; $\beta_{5}\left(\mathrm{~B}_{5}\right)=1,0$.

У результаті синтезу цих ознак маємо групу логічно пов'язаних розумових елементів, які можна представити символічною моделлю 
ієрархічного типу: $\mathrm{A}\left(\mathrm{B}_{1}, \mathrm{~B}_{2}, \mathrm{~B}_{3}, \mathrm{~B}_{4}, \mathrm{~B}_{5}\right)$. Кожний елемент у цій системі набуває означений ваговий коефіцієнт $\beta(\mathrm{B})=1,0$ залежно від його соціальної значимості. У нашому аспекті викладена проблема полягає в тому, як визначити ступінь сформованості пізнавальної активності у студента безпосередньо в навчально-виховному процесі, за допомогою якого інструмента можна виміряти цю педагогічну величину у своїй сутності, що має інтегративний характер.

Щоб зберегти системність у структурі зумовленого поняття, ми здійснювали вимір еталонними складниками вищої характеристики критерію роздільно, тому що процес його формування відбуваються нерівномірно і не завжди гармонійно (за ознаками $\mathrm{B}_{1}, \mathrm{~B}_{2}, \mathrm{~B}_{3}, \mathrm{~B}_{4}, \mathrm{~B}_{5}$ ). А внаслідок стохастичної природи інтегративного процесу, у результаті якого формується максимально досяжний показник, можна спостерігати нескінченний ряд його проміжних станів. Щоб фіксувати деякі окремі стани даного процесу (i як можна точніше), уведемо вимірювальні підструктури для кожної еталонної ознаки:

$\mathrm{C}_{1}$ - студент не відчуває ніякої потреби в пізнавальній активності і не розуміє її суспільної значимості; коефіцієнт сформованості ознаки дорівнює $\alpha_{1}\left(C_{1}\right)=0,0$;

$\mathrm{C}_{2}-$ студент досить рідко відчуває потребу в пізнавальній активності і не усвідомлює її соціальної значимості; коефіцієнт сформованості ознаки $\alpha_{2}\left(\mathrm{C}_{2}\right)=0,2$;

$\mathrm{C}_{3}-$ студент іноді відчуває потребу в пізнавальній активності i Водночас починає розуміти ії соціальну значимість; $\alpha_{3}\left(\mathrm{C}_{3}\right)=0,5$;

$\mathrm{C}_{4}$ - студент часто відчуває потребу в пізнавальній активності, але не завжди переконаний у їі суспільній сутності і значимості; $\alpha_{4}\left(\mathrm{C}_{4}\right)=0,7$;

$\mathrm{C}_{5}$ - студент досить часто відчуває потребу в пізнавальній активності й усвідомлює її суспільну значимість і цінність; $\alpha_{5}\left(\mathrm{C}_{5}\right)=0,9$;

$\mathrm{C}_{6}$ - студент завжди відчуває потребу в пізнавальній активності і завжди переконаний у іiї значимості для особистості і суспільства; $\alpha_{6}\left(\mathrm{C}_{6}\right)=1,0$;

$\mathrm{C}_{7}-$ повна відсутність мотивації і прагнення до удосконалення своєї пізнавальної активності; $\alpha_{7}\left(\mathrm{C}_{7}\right)=0.0$;

$\mathrm{C}_{8}-$ слабко усвідомлена мотивація $\mathrm{i}$ досить нечасті спроби до удосконалення пізнавальної активності; $\alpha_{8}\left(\mathrm{C}_{8}\right)=0,2$;

$\mathrm{C}_{9-}$ при низькій мотивації виявляється нестійке прагнення до удосконалення своєї пізнавальної активності ; $\alpha_{9}\left(\mathrm{C}_{9}\right)=0,5$;

$\mathrm{C}_{10}$ - мотивація усвідомлена $\mathrm{i}$ досить стійка, студент прагне удосконалювати свою пізнавальну активність; $\alpha_{10}\left(\mathrm{C}_{10}\right)=0,7$;

$\mathrm{C}_{11}$ - мотивація усвідомлена $\mathrm{i}$ стійка, студент постійно прагне до удосконалення своєї пізнавальної активності ; $\alpha_{11}\left(\mathrm{C}_{11}\right)=0,9$;

$\mathrm{C}_{12}$ - мотивація сильна, усвідомлена і стійка; студент цілеспрямовано $\mathrm{i}$ систематично вдосконалює свою діяльність, самого себе й обставини; $\alpha_{12}\left(\mathrm{C}_{12}\right)=1,0$;

$\mathrm{C}_{13}$ - розумові операції й уміння, властивості мислення для розв'язання поставленої задачі не спостерігаються; $\alpha_{13}\left(\mathrm{C}_{13}\right)=0,0$; 
$\mathrm{C}_{14}$ - розумові операції й уміння, властивості мислення для розв'язання поставленої задачі слабкі; $\alpha_{14}\left(\mathrm{C}_{14}\right)=0,2$

$\mathrm{C}_{15}$ - студент виявляє розумові уміння $\mathrm{i}$ властивості мислення для розв'язання поставленої задачі, але недостатньо; $\alpha_{15}\left(\mathrm{C}_{15}\right)=0,5$;

$\mathrm{C}_{16}$ - студент виявляє розумові уміння i властивості мислення для розв'язання поставленої задачі в необхідній мірі ; $\alpha_{16}\left(\mathrm{C}_{16}\right)=0,7$;

$\mathrm{C}_{17}$ - студент виявляе необхідні результативні розумові уміння $\mathrm{i}$ властивості мислення; $\alpha_{17}\left(\mathrm{C}_{17}\right)=0,9$;

$\mathrm{C}_{18}$ - студент виявляє успішні розумові уміння і властивості мислення.; $\alpha_{18}\left(\mathrm{C}_{18}\right)=1,0$;

$\mathrm{C}_{19}-$ у студента відсутнє прагнення до самовдосконалення і самовияву; $\alpha_{19}\left(\mathrm{C}_{19}\right)=0,0$;

$\mathrm{C}_{20}$ - заради досягнення мети студент іноді робить спроби до самовдосконалення і самовияву; $\alpha_{20}\left(\mathrm{C}_{20}\right)=0,2$;

$\mathrm{C}_{21}$ _а необхідності студент намагається самоудосконалюватися $\mathrm{i}$ самовиявлятися; $\alpha_{21}\left(\mathrm{C}_{21}\right)=0,5$;

$\mathrm{C}_{22}$ - учень самоудосконалюється і самовиявляється; $\alpha_{22}\left(\mathrm{C}_{22}\right)=0,7$;

$\mathrm{C}_{23}-$ самовдосконаленість особистості містить іноді оригінальний творчий компонент; $\alpha_{23}\left(\mathrm{C}_{23}\right)=0,9$;

$\mathrm{C}_{24}$ - перетворення дійсності і самого себе в ній у студента завжди має творчий перетворювальний характер; $\alpha_{24}\left(\mathrm{C}_{24}\right)=1,0$;

$\mathrm{C}_{25}$ - порівнянність і пізнавальний інтерес у розв'язанні задач відсутній, існує психологічний бар'єр між студентом і викладачем; $\alpha_{25}\left(\mathrm{C}_{25}\right)=$ 0,0

$\mathrm{C}_{26}$ - слабко усвідомлена порівнянність, відсутні пізнавальні інтереси, у своїх невдачах обвинувачують в основному викладачів; $\alpha_{26}\left(\mathrm{C}_{26}\right)=0,2$;

$\mathrm{C}_{27}$ - нерівномірність самостійності, різні пізнавальні зусилля; $\alpha_{27}\left(\mathrm{C}_{27}\right)=0,5$;

$\mathrm{C}_{28}$ - періодичні пізнавальні інтереси, вузьке коло друзів, суб'єктивне ставлення до викладачів; $\alpha_{28}\left(\mathrm{C}_{28}\right)=0,7$;

$\mathrm{C}_{29}$ - самостійність висока, добре розвинуті пізнавальні інтереси, співробітництво з викладачами і друзями; $\alpha_{29}\left(\mathrm{C}_{29}\right)=0,9$;

$\mathrm{C}_{30-}$ глибокі пізнавальні інтереси, $\epsilon$ ініціатором активного співробітництва з товаришами і викладачами; $\alpha_{30}\left(\mathrm{C}_{30}\right)=1$.

За допомогою цієї побудови доходимо до більш розгалуженої системи ознак критерію, структура якого в загальному вигляді така: $\mathrm{A}(\mathrm{B} 1(\mathrm{C} 1 \kappa) \mathrm{B} 2(\mathrm{C} 2 \kappa) . \mathrm{Be}(\mathrm{Cек}))$. У нашому прикладі індекс «е» показує число елементів в еталоні критерію, тобто е $=1,4$, а індекс «к»- кількість градацій, узятих для кількісної характеристики цього елемента, к =1,6.

Зі структури критерію визначено методику виміру еталонних ознак i алгоритм обчислювальних процедур. Так, у досвіді у випробуваного встановлюється фактичний ступінь сформованості досліджуваної ознаки «Ве», що потім фіксується за однією з відповідних градацій «Сек» у виді числового коефіцієнта: $0,0<\alpha е к$ (Сек) $<1,0$. 
Подальша операція - знаходимо добуток даного показника на відповідний ваговий коефіцієнт:

$\mathrm{Pe}=\beta \mathrm{e}(\mathrm{Be}) \alpha е к($ Сек $)<1,0 \quad$ (2), що надає можливість знайти узагальнений ступінь сформованості ознаки «Ве» на безлічі елементів еталона. Щоб визначити середній ступінь сформованості для кожної пошукової ознаки критерію (у даному випадку «А»), досить скористатися середнім арифметичним: $\mathrm{Pc}=1 / \mathrm{e}(\mathrm{P} 1+\mathrm{P} 2+\ldots . .+\mathrm{Pe})<1,0$

Після цього варто застосувати формулу (1). Отриманий результат покаже рівень сформованості шуканої ознаки в інформаційних одиницях виміру (бітах). Поставимо ще одне питання: яка верхня межа виміру шкали цього критерію? Щоб відповісти на нього, ми повинні допустити, що всі еталонні ознаки в критерії (а виходить, і відповідні їм нижчі елементи) сформовані на всі 100\%. Звідси випливає: Р1(B1) = 1,0; Р2(B2) = 0,8; Р3(В3) $=0,8 ; \mathrm{P} 4(\mathrm{~B} 4)=1,0, \mathrm{P} 5(\mathrm{~B} 5)=1,0$. Середній ступінь сформованості вищої ознаки, відповідно до рівняння (3), буде дорівнювати: $\mathrm{Pc}=0,2(1,0+0,8+0,8$ $+1,0+1,0)=0,92$. Підставимо отриманий результат у формулу:

$$
\mathrm{H}=1,443 \mathrm{p}_{\mathrm{c}} \ln \left(\mathrm{e}^{3} \mathrm{p}_{\mathrm{c}}{ }^{3}+\mathrm{e}^{2} \mathrm{p}_{\mathrm{c}}{ }^{2}+1\right),(4)
$$

де е - кількість ознак (вимірюваних елементів) у розглянутій групі зв'язків критерію; рс - середній ступінь сформованості вимірюваної ознаки; 0,0<Рc $<1,0$.

За формулою (1) виміряється ступінь відповідності досліджуваного об'єкта параметрам структурно-системного критерію. Зробимо розрахунок:

Нмм $=1,443-0,92 \operatorname{Ln}\left(5^{3}\right.$ X $0,92^{3}+5^{2}$ X 0,92 +1$)=5,84$ (біт).

Отже, змінна показника сформованості пізнавальної активності за критерієм буде коливатися в межах: $0,0<\mathrm{H}(\mathrm{p})<5,84$.

Звідси рівні функціонування цієї характеристики для контингенту студентів отримують таку якісно-кількісну градацію:

1.) Якщо значення знайденого показника Нх опиняється в межах напівінтервалу $0,00<\mathrm{Hx}<0,82$, то можна вважати, що випробуваний належить до дуже низького рівня пізнавальної активності, в якому студенти негативно ставляться до навчання як до виду діяльності. Вони не відчувають ніякої потреби в пізнавальній активності i не розуміють їі суспільної значимості. У них спостерігається повна відсутність мотивації й прагнень до удосконалення своєї пізнавальної активності відповідно й пізнавальний інтерес до розв’язання задач відсутній. Кожен 3 цих студентів потребує індивідуального підходу до розвитку пізнавальної активності.

2.) Якщо значення показника Нх опиняється в межах напівінтервалу $0,82<\mathrm{Hx}<2,03$, то випробуваний може бути віднесений до низького рівня сформованості пізнавальної активності. Студенти, які віднесені до цього рівня, не вміють мобілізовувати свої пізнавальні зусилля, навіть при належному зовнішньому стимулюванні, виявляють слабко усвідомлену мотивацію і досить нечасті спроби до удосконалення пізнавальної активності.

Представники цієї групи потребують постійних нагадувань про студентські обов'язки, інакше вони не розпочинають виконання навчальних завдань. Такі студенти намагаються уникати розумового напруження, їх навчальна 
діяльність характеризується низьким рівнем самостійності, неспроможністю здійснювати самоконтроль і правильно оцінювати результати своєї роботи, вони або механічно наслідують інших, або списують готове. Студенти цієї групи не цікавляться жодною навчальною дисципліною і не в змозі навіть тимчасово захопитися яким-небудь видом діяльності. Вони звикли, що їх постійно звинувачують у лінощах, їхня самооцінка власних пізнавальних можливостей не відповідає дійсності. Студенти або зневірилися у власних можливостях і не приступають до завдань, які могли б виконати самостійно, або вважають, що багато чого зможуть, якщо захочуть, тобто мають нічим не виправданий високий рівень домагань, їм бракує самокритичності.

3.) Якщо значення знайденого показника Нх опиняється в межах напівінтервалу 2,03 < Нx < 3,35, то випробуваного можна віднести до середнього рівня пізнавальної активності. Пізнавальна активність представників цього рівня характеризується нерівномірністю й перебуває в прямій залежності від зовнішнього стимулювання. На різних заняттях, навіть 3 одного й того ж предмета, вони можуть виявляти неоднакові пізнавальні зусилля. За низької мотивації виявляється нестійке прагнення до вдосконалення власної пізнавальної активності.

Самостійне здобування знань у них має епізодичний характер. До контролю та оцінки результатів власної діяльності вдаються дуже рідко. Для багатьох $з$ них стало звичним розпочинати виконання навчальних завдань тільки після нагадування. Представники цієї групи не мають постійного інтересу до жодної дисципліни, які вивчають у ВНЗ, їхні захоплення окремими видами навчальної діяльності епізодичне. Вони звикли задовольнятися незначними успіхами в навчанні. Проте репутація невстигаючого студента в групі їм неприємна. За відсутності належного контролю можуть списувати, розраховують на підказування. Результати їх навчальної діяльності досить рідко заслуговують на схвалення викладача, тому вони не звикли зосереджувати на них свою увагу i не вдаються до самооцінки чи порівняння себе 3 кращими студентами. У навчальній діяльності не ставлять для себе цілей, складніших від тих, яких досягли.

4.) Якщо значення знайденого показника Нх опиняється в межах напівінтервалу 3,35 < Нx $<4,77$, то випробуваного можна віднести до високого рівня сформованості пізнавальної активності. Цей рівень характерний для тих студентів, у яких потреба в пізнавальній діяльності виявляється лише стосовно окремих предметів. Процес навчання їх захоплює періодично. Інколи, турбуючись про оцінку успішності, а не про знання, вони виявляють егоїзм і нездоровий дух суперництва. Це спричиняє неправильні стосунків 3 товаришами й викладачами: звужується коло контактів 3 одногрупниками, формується хибне суб'єктивне ставлення до викладача.

\%.) Якщо значення показника Нх, опиняється в межах напівінтервалу $4,77<\mathrm{HX}<5,84$, то випробуваний має найвищий рівень пізнавальної активності. Цей рівень притаманний тим студентам, у яких яскраво виявлена потреба в пізнавальній діяльності. Вони самостійно розпочинають 
розв'язання навчальних завдань, успішно контролюють процес їх виконання i відповідно оцінюють результати власної роботи. Мають сильну, усвідомлену та стійку мотивацію. Вони мають глибокі пізнавальні інтереси до кількох предметів, реалізуючи які, ці студенти систематично виходять за межі вишівської програми, їх захоплює сам процес навчання, пізнання. Престижний бік навчальної діяльності - на другому плані. Вони не виявляють надмірного занепокоєння 3 приводу оцінки їх успішності, якщо вона не відповідає сподіванням. 3 усіма труднощами, що виникають у процесі навчання, намагаються впоратися самостійно. 3-поміж інших студентів вони відрізняються високорозвиненою працьовитістю, тому для викладача $є$ опорою в роботі 3 групою; їх часто викликають відповідати тоді, коли інші не можуть (під час закріплення важкого навчального матеріалу, пригадування раніше пройденого).

Виявляючи старанність під час виконання всіх навчальних завдань, студенти цієї групи систематично й охоче допомагають іншим, є ініціаторами активного співробітництва 3 товаришами й викладачем у процесі навчання.

Творча активність виявляється через креативний рівень сформованості пізнавального інтересу, творчу самостійність, грунтовне знання програмного матеріалу, володіння елементами знань і навичок понад програму, здатність самостійно конструювати об'єктивно нову орієнтовну основу діяльності, у процесі виконання якої одержується об'єктивно нова інформація.

Висновки. Проведене дослідження не претендує на вичерпне розв’язання всіх аспектів проблеми, що розглядається. Виконана робота дозволяє окреслити перспективи подальшого розроблення питань щодо визначення критеріїв та рівнів пізнавальної активності студентів, щодо розроблення системних методів діагностування рівнів формування пізнавальної активності студентів.

\section{Література}

1. Горбач М. С. Психологічні умови керування розвитком пізнавальної діяльності / М. С. Горбач // Радянська школа. - 1980. -№7. - С. 22-27.

2. Китайгородская Г. А. Метод активизации возможностей личности и коллектива / Галина Александровна Китайгородская. - М. : МГУ, 2001. - 198 с.

3. Проблемы диагностики умственного развития учащихся: [учеб. пособ.] / под ред. 3. И. Калмыковой. - М. : Педагогика, 1975. - 206 с.

Стаття надійшла до редакції 27.05.2012 p.

УДК 371.134

A. С. Чумак,

кандидат пед.наук, ст. викладач, Криворізький педагогічний інститут ДВНЗ «Криворізький національний університет»

\section{ОРГАНІЗАЦІЯ ТВОРЧОЇ ДІЯЛЬНОСТІ НА УРОКАХ ТЕХНОЛОГІЙ ЯК ЗАСІБ ФОРМУВАННЯ КОМПЕТЕНТНОЇ ОСОБИСТОСТІ ШКОЛЯРІВ}

Чумак А.С. Організачія творчої діяльності на уроках технологій як засіб формування компетентної особистості иколярів.

У статті розкрито можливості організачії творчої діяльності на уроках технологій, спрямовані на формування певного комплексу компетенцій в учнів, які розкривають їхню здатність до професійної, творчої діяльності і життєдіяльності, що трунтується на знаннях, иінностях, досвіді, здібностях, набутих завдяки навчанню.

Ключові слова: творчість, урок технології, особистість. 